\title{
Development of Independent Homeschooling Model Primary School Division as the Impact of Covid 19
}

\author{
Maria Veronika Roesminingsih ${ }^{1 *}$ Widya Nusantara ${ }^{1}$ Rivo Nugroho ${ }^{1}$ Putri Rachmadyanti ${ }^{2}$ \\ Ganes Gunansyah ${ }^{2}$
}

\begin{abstract}
${ }^{1}$ Faculty of Education, Department of Non Formal Education, Universitas Negeri Surabaya
${ }^{2}$ Department of Elementary Educational Teacher, Universitas Negeri Surabaya

*corresponding author. Email: roesminingsih@unesa.ac.id,widyanusantara@unesa.ac.id
\end{abstract}

\begin{abstract}
Since the discovery of positive cases of the corona virus in Indonesia in early March 2020 until it broke out in a number of regions at this time, the Government has instructed them to carry out teaching and learning activities at home until an undetermined time to reduce the spread of the virus. Learning activities at home will create a burden not only for children who learn. For parents, the increased burden of having to be a teacher at home, teaching to make assignments, and always monitoring is definitely felt. Especially if you have more than one child, all of whom need assistance in doing assignments from school. Even though the person concerned must also prepare food and other household chores. On this basis, this research was conducted to find an independent homeschooling model for elementary school children who currently have to carry out home learning due to COVID-19. This model will be equipped with various guidelines for parents in order to maximize children's potential in implementing home learning, through the approach. research development from Thiagarajan (4D model). To produce a product that is suitable for validation, it is carried out by 2 experts, namely learning experts and substance experts. The results of this study are expected to be able to overcome the level of saturation of students and parents in implementing learning at home as long as there is COVID-19, it can even be used continuously for parents who will choose to homeschool their children.
\end{abstract}

Keywords: Homeschooling, Independent Elementary School, COVID-19

\section{INTRODUCTION}

The Covid-19 pandemic has not subsided over its spread in Indonesia. All aspects of needs and demands become long-term and short-term impacts, including aspects of health, economy, social, culture, politics, and even education. During the period of quarantine, social distancing, physical distancing until the government enforces a new habit (new normal), early childhood education to higher education has not been activated, because it is feared that it will become the main cluster of virus spread from school to home. The presence of the Covid-19 pandemic, especially in the field of education, brings suffering to parents when he gets additional assignments to accompany their children to learn from home. Parents who previously handed over their children's academic education to schools or teachers now have to take on this role as teachers as well as accompanying children's education. The variety of obstacles faced by parents in learning from home with children is very varied, including learning complaints, quotas, subject matter, assignments, ineffective learning environments, not having electronic devices (cellphones, laptops) and being unable to operate supporting media (zoom-meeting, google -meeting, google-classroom, etc.)

Schools in the network (online) are very hard for teachers, parents and children to feel as a major component in the delivery of material from teacher to student. The teacher provides materials, games, learning methods that are fun and easy to remember so that students do not feel overwhelmed, to review or evaluate learning. Early childhood and children at the primary school level feel the most difficult in this learning because they have to be accompanied by parents or adults in the learning process, for junior high and high school levels they can already operate cellphones or laptops as supporting media for online learning (online). In this research, it will be more indepth at the elementary school level.

At elementary school age a child needs special attention, because at this age character development is very necessary. Character can be formed from an early age, therefore teachers and more and more parents must know what the child's needs 
are. By knowing the needs of children, educators can choose the right materials and methods. The development of basic education learning programs needs to encourage and facilitate the exploration of the educational potential of modern information technology media, the world of work or culture, and the filling of spare time. In addition, it is necessary to develop the habits of students to take advantage of every opportunity to learn and develop themselves, both related to what they learn in their educational units, as well as those related to their daily lives.

Primary education functions to instill values, attitudes, and a sense of beauty, as well as to provide the basics of knowledge, abilities, and reading, writing and numeracy skills as well as the learning capacity of students to continue to secondary education and / or to live in the community, in line with the achievement of national education goals. The primary education level has two functions, namely the function of developing the potential of students psychologically and providing a strong foundation for junior high school education and beyond. While the objectives substantively refer to the goals of national education. In accordance with the principles of education that is open, multi-meaning, democratic and nondiscriminatory, this elementary school education also applies the principle of transfer of students between elementary education units and between primary education pathways with non-formal and informal education channels. The developed curriculum is tailored to the needs and interests of children and combines it with the generally accepted curriculum. The curriculum is made based on everyday life so that children do not experience many obstacles in implementing it.

Most parents feel the heavy burden faced by their children with the application of learning at home from assignments to subjects that are difficult for parents to understand and master. By studying at home, it is not only children who are burdened but also parents, especially mothers, also accept the burden. The problem is that many parents, especially mothers, are not ready. Technically, scientifically and understandingly, skills, and mentally as a teacher. So they were forced to make adjustments. However, homeschooling has become very effective in this covid-19 pandemic, due to all government policies so that there is no spread and transmission of the covid-19 virus that other people may carry or vice versa. If home learning is a government policy in reducing the impact of Covid-19, there are many obstacles so it is very possible that parents take another learning pattern in the form of homeschooling. Homeschooling is an alternative to formal education, on this basis a homeschooling model will be developed that can help parents to overcome their children's learning problems when children feel uncomfortable learning through school programs. Homeschooling itself is an activity to send to school or provide full education to children at home [1]. From several previous studies, it is known that children who study in homeschooling are better than those who attend conventional school. [2]. This is an advantage obtained from implementing homeschooling because there are some parents who are not satisfied with their services to the school system. At its most basic, homeschooling will continue to challenge the concepts of modern education, schooling and the family. Conventional schooling, curriculum, and achievement will be unclear, changing not only participants' conceptions of education but very possibly the wider community [3].

Parents' concerns in the formal schooling system regarding the lack of education in certain academic systems make parents prefer the home schooling system (homeschooling). Of course, there are not a few impacts of the schooling system that have an effect on students, good or bad, which all depend on the personality of each student in accepting or refusing to do or leave. [4] stated that many parents worry that their children will become victims of an unhealthy environment. Although not all children in school become perpetrators of violence. Therefore, many parents shift their children's education to homeschooling. Through homeschooling, parents can actually direct the development and growth of their children according to their talents and interests. Because the results of this education are more personal and flexible. That's why some parents come back to the idea that children's education begins with the family. The family is a place where children develop and grow. Children can develop their own potential and can accept their strengths and weaknesses.

Homeschooling was originally a "Single Homeschooling" which is run by a single family. Then it develops into "Compound Homeschooling", which consists of several families in an environment. When it gets bigger, it will form a "Homeschooling Community" which requires an orderly and structured management. Homeschooling is an option and one of the educational alternatives for parents in improving the quality of education, developing faith in terms of religion (religion) and creating a more enjoyable learning atmosphere, because learning is adapted to conditions at home, so that children feel comfortable always studying at home without being around. pressure from various factors and parties. This is considered fun and effective because children learn according to their daily needs, besides that parents are fully responsible for their children's education, from religion to talents that want to be developed with fun learning methods and adapted to the condition of the child and their family environment.

The choice of self-study method which is carried out at home through homeschooling is based on various supporting aspects, especially from the concerns of parents. Concern about the school environment, the desire of parents to provide moral or religious teaching, and dissatisfaction with academic teaching in other schools [2]. Homeschooling has offered flexible learning for children who may face difficulties in traditional schools. Problems such as racism, special needs in learning, and traditional learning disabilities can be resolved through the implementation of homeschooling [5]. From this explanation, the advantages of choosing self-learning methods through homeschooling have an impact on parental satisfaction on children's learning outcomes. Parents do not worry about their children studying in the formal schooling system which will be affected by negative and bad activities through the environment and peers. Also in this way parents are more able to control and emphasize what subjects are most in need according to the needs of children and society by looking at the conditions and abilities of the children. parents are more able to guide and follow the child's development in a focused and planned manner. 
According to Hold [6] the objectives of implementing homeschooling are; (1) Ensuring the completion of quality primary and secondary education for the academic learning process and life skills; (2) Ensuring equality and easy access to education for every individual for the academic learning process and life skills; (3) Serving students who need academic education and skills flexibly to improve their quality of life. In accordance with these objectives, [7] explains that in implementing Homeschooling, there are several requirements that need to be met by parents who want, including (1) to love children, (2) be creative, (3) patient and friendly with children, (4) Understanding the needs and desires of the child, (5) Knowing the child's abilities and interests, (6) Willing to listen and negotiating, (7) Willing to change, being flexible, and responsive, (8) Understanding the child's physical, psychological, and mood conditions, (9) Having the willingness to want to know the competency standards and content standards of the national curriculum that have been recognized and endorsed by the BSNP (National Education Standards Agency), (10) Having a commitment to study time with children.

Research on the development of a homeschooling model for primary school children as a result of Covid 19 aims to see: the feasibility of the developed model seen from its use and results, so that it can help parents facilitate the learning needs of their children, especially in the Covid 19 era for elementary school levels, especially grade III of elementary school. The selection of the research location was carried out at the Labschool Unesa Lidah Wetan elementary school. The reason for choosing Labschool Unesa Lidah Wetan elementary school is because the conditions in this elementary school are not different from elementary school in general where the level of stress done by parents is quite high, especially if this family has more than two children in school. Where the problem is the task of doing online work together with the problem of only one cellphone and the distribution of accompanying children along with household tasks. Meanwhile, the benefits of this research include helping parents to accompany their children to study at home, while still paying attention to children's development, goals to be achieved and making learning fun / enjoyable.

\section{METHOD}

\subsection{Research Design}

This study uses a development research method. Development research is used because this study aims to produce a product in the form of a Homeschooling model with learning tools. According to [8], development research is a structured study in making plans, developing products, conducting assessments. The research design used the 4D (four-D) model referring to the research and development model from [9]. The main stage in the 4-D development model consists of four stages, namely Define, Design, Develop, and Disseminate. The implementation of the steps in this study is adjusted to the characteristics of the subjects at the research site.
In the Define stage, identification of the content needs of homeschooling and preparation of tools is carried out. In the Design stage, the preparation of a homeschooling implementation guide to the validation stage by learning experts and making learning scenarios until validated by material experts. The last stage is Develop (Development), in this stage a limited trial and implementation is carried out to the Disseminate process.

\subsection{Research Subject}

The subjects in this research on the development of the homeschooling model were the parents of 3 th grade students of Labschool Unesa Lidah Wetan Elementary School who are currently carrying out learning at home, so that the target also includes parents of students who must accompany their children to study. Data to measure the feasibility or validity of the model was obtained from the research instrument in the form of a questionnaire filled in by two validators, namely the validator of the completeness of the model.

To obtain accurate and accountable data, researchers used interviews (online), questionnaires with google form and documentation (portfolios) which would be uploaded or sent via WAG (WhatsApp Group). Data analysis was carried out in a descriptive quantitative manner by calculating the mean or mean (percentage) with very feasible, feasible, less feasible, and unfit criteria.

\section{RESULTS AND DISCUSSION}

\subsection{Identify the Need for Independent Homeschooling Content}

At the data collection stage, it began with interviews with Class 3 teachers and school principals, from here the research team then reviewed the curriculum data, competency standards and syllabus used in Labschool Unesa Lidah Wetan elementary school. Furthermore, the research team identified and collected the material needed to compile the parental guidance module according to the needs.

\subsection{Preparing the Device}

The stages taken in the development of the parent guide module in implementing the independent homeschooling learning model are 1) the planning stage (preparation of the Module Content Outline, 2) the writing stage (Outline preparation / module design, writing draft I, completing draft I to draft II), 3) the review, trial and revision stage (expert review, small group trial and field trial), 4) the finalization and printing stage.

a) The planning stage, which is produced in the planning stage is the module target to be written, the number of modules, and the module material.

b) The writing stage, which is produced from the writing stage is a module output consisting of a cover page, a table of contents, the contents of the material, and a review stage. 


\subsection{Module Validation}

Research data for the Homeschooling guideline module for parents was obtained from validation of media experts, validation of material experts and trials on parents / guardians of class 3 by filling in an instrument in the form of a questionnaire to assess the feasibility of the learning module. The instrument is arranged based on the aspects contained in the grid and uses a Likert scale with a scale ranging from 1 to 5 .

Validation by media experts is carried out to determine the feasibility of the learning module in terms of learning media. At this stage the validation of the learning module is carried out by two experts, namely media experts and learning experts Homeschooling Guidelines for parents who have been printed and provide an assessment by filling out an instrument in the form of a questionnaire specially prepared for material experts. The instrument consists of 24 statement items which are divided into six aspects, namely the introduction aspect (4 statement items), the content aspect ( 7 statement items), the language aspect (13 statement items).

\subsection{Data Analysis}

In the data analysis stage, it becomes the most important stage, because in this stage the media and material expert validation is carried out, 9 learning modules have been compiled. In data analysis, data is presented in the form of validation calculation results and the calculation of the eligibility level criteria.

(a) Module for Coping with Saturated Children Learning, based on the validation of the assessment media of the parent guide module in overcoming learning boredom children has an eligibility level of $94 \%$ (Ninety-four percent) with very feasible criteria.

(b) Module How to Use the Surrounding Environment as a Learning Media, based on the validation of the assessment media for the parental guide module with the title how to use the surrounding environment as a learning medium, it has a feasibility level of $86 \%$ (eighty-six percent) with very feasible criteria.

(c) Module Understanding Children's Intelligence and How to Explore Intelligence

(d) based on the validation of the assessment media of the parental guide module with the title Understanding Children's Intelligence and How to Dig Intelligence, it has a feasibility rate of $91 \%$ (Ninety-One Percent) has very decent criteria.

(e) Module Building Children's Independence and Discipline in Learning, based on the validation of the assessment media of the parent guide module with the title Building Children's Independence and Discipline in Learning, it has a feasibility level of $97 \%$ (ninety-seven percent) having very decent criteria.

(f) Module Getting to Know Homeschooling

(g) based on the validation of the media assessment of the parent guide module with the title Knowing
Homeschooling, it has a feasibility rate of $89 \%$ (eightynine) having very decent criteria.

(h) Independent Homeschooling Assessment Module, based on the validation of the assessment media for the parent guide module with the title Self-Assessment Homeschooling, it has a feasibility level of $89 \%$ (eightynine) has very decent criteria.

(i) Module Preparing a Literacy Rich Environment at Home, based on the validation of the assessment media for the parent guide module with the title Preparing a LiteracyRich Environment at Home, it has a feasibility level of $86 \%$ (eighty-six percent) with very feasible criteria.

(j) Module on the Role of Parents in Educating Children, based on the validation of the media assessment of the parent guide module with the title Knowing Homeschooling, it has a feasibility rate of $89 \%$ (eightynine) having very decent criteria.

(k) Modified K-13 Curriculum Modification Module for Independent Homeschooling Program, based on the validation of the assessment media of the parent guide module with the title Knowing Homeschooling, it has a feasibility level of $89 \%$ (eighty-nine) having very decent criteria.

\section{CONCLUSION}

The provisional results can be concluded that the module or parent's handbook in carrying out homeschooling independently can be declared worthy of use in terms of reviewer assessments. The modules developed include (1) The homeschool model in which there are homeschooling models (2) The role of parents in children's education contains various tips in assisting children (3) Understanding children's intelligence and how to explore children's intelligence (4) Determining the right curriculum, in which there is a schedule of activities, (5) Utilizing daily life as a learning medium, (6) Getting to know various processes of homeschooling evaluation, (7) Overcoming striking and bored children in learning, (8) Building Children's Independence. Mendisiplnkan in learning, (9) Arranging a task-rich study room at home, (10) Recognizing children's talents and interests.

\section{REFERENCES}

[1] A. Adiputro S, "Pengaturan Tentang Tindak Pidana Penistaan Agama di Indonesia.(Studi Kasus Penistaan Agama di Malang, Jawa Timur).” Perpustakaan F. Hukun Undip, 2008.

[2] R. Kunzman and M. Gaither, "Homeschooling: A comprehensive survey of the research," Other Educ., vol. 2, no. 1, pp. 4-59, 2013.

[3] H. E. Lees, "The gateless gate of home education discovery: what happens to the self of adults upon 
discovery of the possibility and possibilities of an educational alternative?" University of Birmingham, 2011.

[4] A. M. Khair and G. F. Fadillah, "Gaya belajar anak Homeschooling (studi pada keluarga pelaku Homeschooling)," Konselor, vol. 6, no. 2, pp. 54-60, 2017.

[5] K. A. Jamaludin, N. Alias, and D. DeWitt, "Research and Trends in the Studies of Homeschooling Practices: A Review on Selected Journals.," Turkish Online J. Educ. Technol., vol. 14, no. 3, pp. 111-119, 2015.
[6] J. Holt and P. Farenga, Teach your own: The John Holt book of homeschooling. Da Capo Lifelong Books, 2003.

[7] A. Muhtadi, "Pendidikan Dan Pembelajaran Di Sekolah Rumah (Home Schooling): Suatu tinjauan teoritis dan praktis," Maj. Ilm. Pembelajaran, 2011.

[8] P. Setyosari, "Dr. H. Punaji. 2013," Metod. Penelit. Pendidik. dan Pengemb.

[9] S. Thiagarajan, D. S. Semmel, and M. I. Semmel, "Instructional development for training teachers of exceptional children." Minneapolis, Minnesota: leadership training institute/special education ..., 1974. 